\title{
ANALISIS KELENGKAPAN PENDOKUMENTASIAN ASUHAN KEPERAWATAN PASIEN DI RUANG RAWAT INAP RUMAH SAKIT TAMPAN PEKANBARU
}

\author{
Neneng Astuti, Yeni Yarnita, Eva Mayasari
}

\begin{abstract}
ABSTRAK
Dokumentasi keperawatan merupakan suatu yang mutlak harus ada untuk perkembangan keperawatan khususnya proses profesionalisasi keperawatan serta mempertahankan keperawatan sebagai suatu profesi yang luhur dan terpandang di masyarakat. Dokumentasi keperawatan dalam bentuk dokumen asuhan keperawatan merupakan salah satu alat pembuktian atas tindakan perawat selama menjalankan tugas pelayanan keperawatan.

Penelitian ini dilakukan dengan cara mengambil seluruh sampel status pasien atau rekam medis pasien yang dirawat pada bulan Januari 2009, dengan jumlah sampel seluruhnya adalah 90 berkas, dengan syarat pasien bukan rawatan ulangan di bulan yang sama.

Hasil analisa data pendokumentasian pada tahap pengkajian mendapatkan skor 56,11\% (kategori cukup), pendokumentasian pada tahap diagnosa keperawatan mendapatkan skor 36,67\% (kategori kurang), pendokumentasian pada tahap perencanaan keperawatan mendapatkan skor 17,11\% (kategori kurang), pendokumentasian pada tahap tindakan keperawatan mendapatkan skor 57,78\% (kategori cukup), pendokumentasian pada tahap evaluasi keperawatan mendapatkan skor 52,78\% (kategori kurang), dan pendokumentasian pada tahap catatan asuhan keperawatan mendapatkan skor 92,22\% (kategori sangat baik). Sehingga diharapkan kepada pihak Rumah Sakit Tampan Pekanbaru untuk dapat meningkatkan mutu dokumentasi keperawatan dengan upaya mengadakan pelatihan yang berkaitan dengan pendokumentasian asuhan keperawatan.
\end{abstract}

Key words: Dokumentasi, Asuhan Keperawatan

\section{PENDAHULUAN}

Keperawatan di Indonesia saat ini masih dalam suatu proses profesionalisasi, yaitu terjadinya suatu perubahan dan perkembangan karakteristik sesuai tuntutan secara global dan lokal. Untuk mewujudkannya maka perawat harus mampu memberikan asuhan keperawatan secara profesional kepada klien. Salah satu bukti asuhan keperawatan yang profesional tercermin dalam pendokumentasian proses keperawatan (Nursalam, 2001).

Dokumentasi keperawatan adalah bagian dari keseluruhan tanggung jawab perawatan pasien. Catatan klinis memfasilitasi pemberian perawatan, meningkatkan kontinuitas perawatan dan membantu mengkoordinasikan pengobatan dan evaluasi pasien (Iyer, 2004). Responsibilitas dan akuntabilitas profesional merupakan salah satu alasan penting dalam pendokumentasian asuhan keperawatan yang akurat (Iyer, 2004). Dokumentasi keperawatan sangat penting bagi perawat dalam memberikan asuhan keperawatan karena pelayanan keperawatan yang diberikan kepada klien membutuhkan catatan dan pelaporan yang dapat digunakan sebagai tanggung jawab dan tanggung gugat dari berbagai kemungkinan masalah yang dialami klien baik masalah kepuasan maupun ketidakpuasan terhadap pelayanan yang diberikan (Hidayat, 2001).

Dokumentasi keperawatan merupakan suatu yang mutlak harus ada untuk perkembangan keperawatan khususnya proses profesionalisasi keperawatan serta mempertahankan keperawatan sebagai suatu profesi yang luhur dan terpandang di masyarakat. Dokumentasi keperawatan dalam bentuk dokumen asuhan keperawatan merupakan salah satu alat pembuktian atas tindakan perawat selama menjalankan tugas pelayanan keperawatan. Penyelenggaraan 
dokumentasi keperawatan telah ditetapkan dalam SK Menkes No. 436/Menkes/SK/VI/1993 tentang Standar Pelayanan Rumah Sakit dan SK Dirjen Yanmed No. YM. 00.03.2.6.7637 tahun 1993 tentang Standar Asuhan Keperawatan.

Rumah Sakit Tampan Pekanbaru merupakan rumah sakit Jiwa tipe A yang digunakan sebagai lahan praktek bagi mahasiswa DIII Keperawatan jalur umum maupun jalur khusus dan juga praktek mahasiswa SI Keperawatan, sehingga perbaikan dan peningkatan mutu asuhan keperawatan selalu dilakukan. Oleh karena itu, penulis tertarik untuk meneliti tentang analisis kelengkapan pendokumentasian asuhan keperawatan pasien di ruang rawat inap Rumah Sakit Tampan Pekanbaru.

\section{METODOLOGI PENELITIAN}

Jenis penelitian ini bersifat deskriptif yaitu untuk / mengetahui gambaran kelengkapan pendokumentasian asuhan keperawatan pasien di ruang rawat inap Rumah Sakit Tampan Pekanbaru, dengan melakukan studi dokumentasi asuhan keperawatan pasien yang telah menjalani rawatan selama bulan Januari 2009. Penelitian ini dilakukan dengan cara mengambil seluruh sampel status pasien atau rekam medis pasien yang dirawat pada bulan Januari 2009, dengan jumlah sampel seluruhnya adalah 90 berkas, dengan syarat pasien bukan rawatan ulangan di bulan yang sama. Alat yang digunakan dalam penelitian ini adalah Standar Asuhan Keperawatan Depkes RI tahun 1997. Adapun cara penilaian penggunaan instrumen dalam penelitian ini adalah bila aspek yang dinilai sesuai dengan Standar Asuhan keperawatan maka diberi tanda "V" dan apabila aspek yang dinilai tidak sesuai dengan Standar Asuhan keperawatan maka diberi tanda " $\mathrm{C}$ ".

Analisis data dilakukan secara manual yaitu berdasarkan skore atau hasil penjumlahan jawaban nilai "V" yang didapat dengan perhitungan rumus sebagai berikut:

Persentase $=($ Jumah berkas $/$ Jumlah Total $)$

$$
\mathrm{x} 100 \%
$$

Hasil akhir dari score disajikan dalam bentuk tabel dan dihitung prosentasenya untuk masing-masing aspek sesuai kelengkapan pendokumentasian asuhan keperawatan pada status pasien, dengan kriteria sebagai berikut:

a. Sangat baik bila $76-100 \%$ proses keperawatan (pengkajian, diagnosa, perencanaan, pelaksanaan dan evaluasi) didokumentasikan secara lengkap sesuai standar asuhan keperawatan

b. Baik bila $65-75 \%$ proses keperawatan (pengkajian, diagnosa, perencanaan, pelaksanaan dan evaluasi) didokumentasikan secara lengkap sesuai standar asuhan keperawatan

c. Cukup bila 55-64\% proses keperawatan (pengkajian, diagnosa, perencanaan, pelaksanaan dan evaluasi) didokumentasikan secara lengkap sesuai standar asuhan keperawatan

D. Kurang bila $<55 \%$ proses keperawatan (pengkajian, diagnosa, perencanaan, pelaksanaan dan evaluasi) didokumentasikan secara lengkap sesuai standar asuhan

\section{HASIL DAN PEMBAHASAN}

Pengkajian adalah tahap awal dari proses keperawatan dan merupakan suatu proses yang sistematis dalam pengumpulan data dan berbagai sumber data untuk mengevaluasi dan mengidentifikasi status kesehatan klien (Iyer, 2004)

Tabel 1. Data pendokumentasian tahap pengkajian keperawatan

\begin{tabular}{|l|l|l|l|}
\hline No & Aspek yang dinilai & f & $\%$ \\
\hline
\end{tabular}




\begin{tabular}{|c|l|c|c|}
\hline 1 & $\begin{array}{l}\text { Mencatat data yang dikaji } \\
\text { sesuai dengan pedoman } \\
\text { pengkajian }\end{array}$ & 41 & 45.56 \\
\hline 2 & $\begin{array}{l}\text { Data dikelompokkan (bio- } \\
\text { psiko-sosial-siritual) }\end{array}$ & 41 & 45.56 \\
\hline 3 & $\begin{array}{l}\text { Data dikaji sejak pasien } \\
\text { masuk sampai pulang }\end{array}$ & 85 & 94.44 \\
\hline 4 & $\begin{array}{l}\text { Masalah dirumuskan } \\
\text { berdasarkan kesenjangan } \\
\text { antara status kesehatan dan } \\
\text { norma serta pola fungsi } \\
\text { kehidupan }\end{array}$ & 35 & 38.89 \\
\hline & \multicolumn{4}{|c|}{ Total } & $\mathbf{2 0 2}$ & $\mathbf{5 6 . 1 1}$ \\
\hline
\end{tabular}

Dari data hasil tahap pengkajian pada tabel 1 didapatkan skore 56,11\% dengan kategori cukup. Pengkajian yang dilakukan oleh perawat/di RS Tampan Pekanbaru mengunakan format yang telah disediakan dalam bentuk chek list dan isian singkat. Sebenarnya hal ini memudahkan perawat untuk melakukan pengkajian secara urut, sistematis dan lengkap karena perawat sudah diatahkan sesuai dalam format. Perawat tidak perlu lagi mengingat-ingat atau berpikir terlalu lama untuk menanyakan halhal yang ingin dikaji kepada pasien.

Tabel 2. Data pendokumentasian tahap diagnosakeperawatan

\begin{tabular}{|c|c|c|c|}
\hline No & Aspek yang dinilai & f & $\%$ \\
\hline 1 & $\begin{array}{l}\text { Diagnosa keperawatan } \\
\text { berdasarkan masalah } \\
\text { yang telah dirumuskan }\end{array}$ & 33 & 36.67 \\
\hline 2 & $\begin{array}{l}\text { Diagnosa keperawatan } \\
\text { mencerminkan PE/PS }\end{array}$ & 33 & 36.67 \\
\hline 3 & $\begin{array}{l}\text { Merumuskan diagnosa } \\
\text { keperawatan } \\
\text { aktual/resiko }\end{array}$ & 33 & 36.67 \\
\hline & Total & 99 & 36.67 \\
\hline
\end{tabular}

Perumusan diagnosa keperawatan yang baik harus menggambarkan komponen problem, etiologi, symptom dan sign serta berdasarkan kesenjangan antara status kesehatan normal dengan pola fungsi kebutuhan pasien (Effendy, 1995). Untuk dapat merumuskan diagnosa keperawatan dibutuhkan kemampuan analisis yang tinggi sehingga diperlukan sumber daya manusia yang capable dan mempunyai motifasi kuat untuk maju serta berpandangan maju (futuristic). Dari data hasil tahap pengkajian pada tabel 1 didapatkan skore 36,67\%, dengan kategori kurang. Pada status pasien yang telah dikaji terlihat bahwa perawat hanya memilih saja diagnosa keperawatan yang telah disediakan di bagian samping format pengkajian. Hal ini memang lebih memudahkan perawat akan tetapi juga dapat menyebabkan perawat menjadi malas dan kurang inisiatif untuk menganalisa data lalu merumuskan diagnosa keperawatan sendiri apabila ditemukan data yang berbeda. Kondisi demikian juga menimbulkan kualitas pendokumentasian diagnosa keperawatan menjadi monoton. Disamping itu pada perumusan diagmosa aktual masih ada beberapa yang tidak mencantumkan sign atau symptom yang menjadi persyaratan utama bahwa diagnosa itu dikatakan aktual.

Tabel 3. Data pendokumentasian tahap perencanaan keperawatan

\begin{tabular}{|c|c|c|c|}
\hline No & Aspek yang dinilai & f & $\%$ \\
\hline 1 & $\begin{array}{ll}\text { Rencana } & \text { tindakan } \\
\text { berdasarkan } & \text { diagnosa } \\
\text { keperawatan } & \end{array}$ & 12 & 13.33 \\
\hline 2 & $\begin{array}{l}\text { Rencana tindakan disusun } \\
\text { menurut urutan prioritas }\end{array}$ & 12 & 13.33 \\
\hline 3 & $\begin{array}{lr}\text { Rumusan } & \text { tujuan } \\
\text { mengandung } & \text { komponen } \\
\text { pasien/subjek, perubahan } \\
\text { perilaku, kondisi pasien, dan } \\
\text { atau kriteria }\end{array}$ & 19 & 21.11 \\
\hline 4 & $\begin{array}{l}\text { Rencana tindakan mengacu } \\
\text { pada tujuan dengan kalimat } \\
\text { perintah, terinci dan jelas }\end{array}$ & 15 & 16.67 \\
\hline 5 & $\begin{array}{l}\text { Rencana tindakan } \\
\text { menggambarkan } \\
\text { keterlibatan pasien/keluarga }\end{array}$ & 15 & 16.67 \\
\hline 6 & $\begin{array}{lr}\text { Rencana } & \text { tindakan } \\
\text { menggambarkan } & \text { kerjasama } \\
\text { dengan tim kesehatan lain }\end{array}$ & 19 & 21.11 \\
\hline & che & 77 & 17. \\
\hline
\end{tabular}

Perencanaan merupakan tahap selanjutnya setelah pengkajian dan penentuan diagnosa keperawatan. Perencanaan juga merupakan petunjuk 
tertulis yang menggambarkan secara tepat mengenai rencana tindakan yang dilakukan terhadap pasien sesuai dengan tingkat kebutuhan berdasarkan diagnosa keperawatan yang muncul. Untuk itu rencana tindakan yang baik tentunya harus berdasarkan pada diagnosa keperawatan yang telah dirurnuskan. Pada status pasien yang telah dikaji terlihat pendokumentasian tahap perencanaan mendapat skore $17,11 \%$ (kategori kurang). Dari tabel perencanaan yang dibuat oleh perawat masih banyak beberapa aspek yang belum memenuhi standar asuhan keperawatan.

Penentuan prioritas masalah juga terdapat dalam tahap perencanaan ini. prioritas tertinggi diberikan kepada masalah atau diagnosa keperawatan yang, bersifat mengancam kehidupan atau keselamatan pasien Effendy (1995). Penentuan prioritas dilakukan karena tidak semua masalah dapat diatasi secara bersamaaan. Oleh karena itu hirarki Maslow tentang kebutuhan dasar rnanusia merupakan pedoman dalan rnenentukan prioritas dengan memperperhatikan keluhan utama pasien. Selain itu juga masih terlihat penulisan rencana tindakan keperawatan yang tidak teratur dan kurang mengacu pada diagnosa keperawatan yang telah ditetapkan. Di dalam perencanaan juga perlu diperhatikan pcrumusan tujuan yang hendak dicapai dari intervensi yang telah diberikan. Dengan adanya tujuan ini akan mempermudah perawat di dalam melakukan evaluasi. Adanya perolehan skore yang masih kurang dari standar tersebut menyebabkan perawat mengalami kesulitan di dalam melakukan evaluasi.

Keterlibatan pasien dan keluarga juga harus diikutsertakan di dalam penetapan rencana keperawatan. Karena antara perawat, pasien dan keluarga harus bekerjasama di dalam intervensi agar dapat mencapai tujuan dengan baik. Begitu juga kerjasama dengan tim kesehatan lain juga sangat dibutuhkan untuk mengatasi masalah medis secara kolaborasi

Tabel 4. Data pendokumentasian tahap tindakan keperawatan

\begin{tabular}{|c|c|c|c|}
\hline No & Aspek yang dinilai & f & $\%$ \\
\hline 1 & $\begin{array}{l}\text { Tindakan yang dilaksanakan } \\
\text { mengacu pada rencana } \\
\text { keperawatan }\end{array}$ & 15 & $\begin{array}{c}16.6 \\
7\end{array}$ \\
\hline 2 & $\begin{array}{l}\text { Perawat mengobservasi respon } \\
\text { pasien terhadap tindakan } \\
\text { keperawatan }\end{array}$ & 82 & $\begin{array}{c}91.1 \\
1\end{array}$ \\
\hline 3 & $\begin{array}{l}\text { Revisi tindakan berdasarkan } \\
\text { hasil evaluasi }\end{array}$ & 43 & $\begin{array}{c}47.7 \\
8\end{array}$ \\
\hline 4 & $\begin{array}{l}\text { Semua tindakan yang telah } \\
\text { dilaksanakan dicatat ringkas } \\
\text { dan jelas }\end{array}$ & 68 & $\begin{array}{c}75.5 \\
6\end{array}$ \\
\hline & Total & 208 & 57. \\
\hline
\end{tabular}

Pelaksanaan atau tindakan adalah pengelolaan dan perwujudan dari rencana yang telah disusun pada tahap perencanaan. Pada tahap pelaksanaan ini dokumentasi menjadi sangat penting karena merupakan pernyataan dari kegiatan atau aktivitas yang otentik dari perawat. Dokumentasi tentang pasien memberi bukti tindakan mandiri dan kolaboratif yang dilakukan perawat, respon pasien terhadap tindakan keperawatan dan perubahan-perubahan yang terjadi, Carrol (1998).

Skore yang didapat secara keseluruhan pada tahap pelaksanaan ini adalah 57,78\% (kategori cukup). Namun pada aspek pelaksanaan evaluasi tiap tindakan yang telah dilakukan hanya mendapat skore 16,67 $\%$ (kategori kurang). Dan perolehan skore ini akhirnya mempengaruhi aspek yang lain yaitu pelaksanaan revisi tindakan hanya mendapat skore 47,78 \%, (kategori kurang).

Tabel 5. Data pendokumentasian tahap evaluasi keperawatan

\begin{tabular}{|c|c|c|c|}
\hline No & Aspek yang dinilai & f & $\%$ \\
\hline 1 & $\begin{array}{l}\text { Evaluasi mengacu } \\
\text { pada tujuan }\end{array}$ & 47 & 52.22 \\
\hline 2 & Hasil evaluasi dicatat & 48 & 53.33 \\
\hline & Total & 95 & 52.78 \\
\hline
\end{tabular}


Evaluasi adalah mengkaji respon pasien terhadap tindakan keperawatan yang telah dilakukan oleh perawat dengan mengacu pada standar atau kriteria hasil yang telah ditetapkan pada rumusan tujuan. Terlihat pada status pasien yang telah dikaji bahwa kriteria keherhasilan yang dapat digunakan sebagai dasar evaluasi ini tidak selalu dicantumkan sehingga evaluasi yang diilakukan kurang mengacu pada tujuan. Skore yang didapat adalah 52,78\% (kategori kurang) dan perolehan skore ini dipengaruhi oleh aspek perumusan tujuan dalam perencanaan sebelumnya.

Tabel 6. Data pendokumentasian catatan asuhan keperawatan

\begin{tabular}{|c|c|c|c|}
\hline No & Aspek yang dinilai & $\mathbf{f}$ & $\%$ \\
\hline 1 & $\begin{array}{l}\text { Ditulis pada format } \\
\text { yang baku }\end{array}$ & 90 & 100 \\
\hline 2 & $\begin{array}{l}\text { Pencatatan } \\
\text { dilakukan sesuai } \\
\text { dengan tindakan } \\
\text { yang dilaksanakan }\end{array}$ & 89 & 98.89 \\
\hline 3 & $\begin{array}{l}\text { Pencatatan ditulis } \\
\text { dengan } \\
\text { ringkas, jelas, } \\
\text { yang baku dan } \\
\text { benar }\end{array}$ & 89 & 98.89 \\
\hline 4 & $\begin{array}{l}\text { Setiap melakukan } \\
\text { tindakan/kegiatan, } \\
\text { perawat } \\
\text { mencantumkan } \\
\text { nama jelas/paraf, } \\
\text { tanggal dan jam } \\
\text { tindakan }\end{array}$ & 57 & 63.33 \\
\hline 5 & $\begin{array}{l}\text { Berkas catatan } \\
\text { keperawatan } \\
\text { disimpan sesuai } \\
\text { dengan ketentuan } \\
\text { yang berlaku }\end{array}$ & 90 & 100 \\
\hline & TOTAL & 415 & 92.22 \\
\hline
\end{tabular}

Pendokumentasian catatan tindakan keperawatan yang telah diberikan kepada pasien secara keseluruhan mendapat skore $92.22 \%$ (kategori sangat baik). Faktor yang dapat mempengaruhi hal tersebut adalah perawat telah aktif dalam pencatatan dengan mencantumkan paraf atau nama terang pada catatan tindakan keperawatan serta menyimpan semua berkas pasien yang sudah pulang dengan baik dan rapi di rekam medis.

\section{DAFTAR PUSTAKA}

Burley, J.T.; Doenges, M.E.; Moorhouse, M.F. (1998). Penerapan proses keperawatan dan diagnosa keperawatan. Edisi 2. Jakarta: EGC

Carrol. (1998). Approach of nursing process. St. Louis: Mosby

Carpenito, L.J. (1999). Rencana asuhan keperawatan dan dokumentasi keperawatan. Edisi 2. Jakarta: EGC

Effendy N. (1995). Pengantar proses keperawatan. Jakarta: EGC

Helena, N.; Keliat, B.A.; Pandjaitan, R.U. (2005). Proses keperawatan kesehatan jiwa. Edisi 2. Jakarta: EGC

Hidayat, A.A.A. (2004). Pengantar konsep dasar keperawatan. Jakarta: Salemba Medika

Hartati; Handoyo; Anis, M.M. (2008). Analisis kelengkapan dokumentasi proses keperawatan pasien rawat inap di RSU PKU Muhammadiyah Gombang Jawa Tengah. Di buka pada tanggal 31 Oktober 2008. Di: http://info.stikesmuhgombang.ac.id/ed isi2handoyo1.doc

Iyer, P.W.; Camp, N.H. (2004). Dokumentasi keperawatan suatu pendekatan proses keperawatan. Edisi 3. Jakarta: EGC

Nursalam. (2001). Proses dan dokumentasi konsep dan praktik. Jakarta: Salemba Medika

Notoatmodjo, S. (2002). Metodologi penelitian kesehatan. Jakarta: Rineka Cipta

Wartonah, T. (2006). Kebutuhan dasar manusia dan proses keperawatan. Edisi 3. Jakarta: Salemba Med 